[8] Dani Departamentu orhanizatsiino-administratyvnoi roboty ta analitychnoho zabezpechennia Administratsii derzhavnoi prykordonnoi sluzhby Ukrainy. Available at: https://dpsu.gov.ua

[9] Kostashchuk, I. I.; Lazhnik, V. Y., Fedoniuk, V. S. (Eds.) (2005). Osoblyvosti natsionalnoi polityky v konteksti intehratsii Ukrainy do YeS (na prykladi Chernivetskoi oblasti). Yevropeiski intehratsiini protsesy i transkordonne spivrobitnytstvo: mizhnarodni vidnosyny, ekonomika, polityka, heohrafiia, istoriia, pravo. Lutsk: RVV „Vezha” Volyn. derzh. un-tu im. Lesi Ukrainky, 445-446.

[10] Legea № 21/1991 a cetățeniei române. Available at: https://lege5.ro/Gratuit/geztmnrrge/legea-nr21-1991-a-cetateniei-romane

[11] Rishennia No. 8/2000 Rady Yevrorehionu «Verkhnii Prut» «Pro priorytetni sfery ekonomichnoi ta sotsialnoi diialnosti v Yevrorehioni «Verkhnii Prut». Available at: http://www.bukoda.gov.ua/page/evroregion-verkhnii-prut

[12] Maritime Delimitation in the Black Sea (Romania v. Ukraine). Judgement. Availablr at: http:// www.icj-cij.org/en/case/132/judgments

[13] Zakon Ukrainy «Pro osnovy natsionalnoi bezpeky Ukrainy», pryiniatyi Verkhovnoiu radoiu Ukrainy 19.06.2003 r., zi zminamy ta dopovnenniamy vid 23.12.2014 r. Available at: http://zakon4.rada.gov.ua/ laws/show/964-15

\title{
"MAGNIFICENT EDIFICE OF THE HISTORY OF SLAVIC LITERATURES": Y. BOYKO-BLOKHIN'S "PROJECT"
}

\author{
Olga Teterina \\ Department of Ukrainian Literature History, Theory of Literature and Literary Art \\ Institute of Philology of Taras Shevchenko National University of Kyiv \\ 14 Shevchenko blvd., Kyiv, Ukraine, 10030 \\ olgateterina@ukr.net
}

\begin{abstract}
The article deals with Y. Boyko-Blokhin's approach to the problem of comparative analysis of Slavic literatures in the context of contemporary comparative study (U. Weisstein, R. Wellek, D. Ďurišin, A. Dima, D. Nalivayko, D. Chizhevsky). The careful attention of the scholar to "peculiarities" of national development of literatures as a subject of the research is emphasized. Specifically, the interpretation by Y. Boyko-Blokhin of such concepts as "interaction" (not only as a rapprochement, but also as a mutual repulsion) and "influence" (primarily as a creative transformation of foreign artistic and aesthetic experience, and hence, as an impetus, impulse for own original creation) is thought through.

The opinion of the scholar as to characteristic aspects of the comparative study of East Slavic literatures is analyzed and the emphasis is given to the researcher's close attention to the question of national features of each of these literatures. The efficiency and potential of Y. Boyko-Blokhin's concept of comparative study of East Slavic literatures, aimed at understanding of their place in Common Slavic and West European literary space are substantiated. The importance of the scholar's thoughts about the need for "reformatting" ("reorienting") of the Slavic paradigm for the further development of this science (in view of unjustified "domination" of Russian literature over Ukrainian and Byelorussian literatures) is underlined.

The consideration is given to Y. Boyko-Blokhin's approach ("project") to compilation of the history of Slavic literatures (vector of which is oriented from the study of peculiarities of literary works towards comprehension of the style as a unifying principle), with an emphasis on comparison of national development trends. The recognition in this context of the progress of other art forms is regarded as fully compliant with the special attention paid by contemporary comparative studies to the problem of literature in the art system (U. Weisstein, D. Chizhevsky, D. Nalivayko)

The great importance for the continuous progress of Ukrainian comparative literature of the views of Y. Boyko-Blokhin, who developed traditions of national comparative studies and at the same time used the latest West European methodology, given the impossibility of its full-fledged advance during the Soviet period, is accentuated. The relevance of the scholar's thoughts and ideas for comparative world literature even nowadays is demonstrated.
\end{abstract}

Keywords: comparative history of Slavic literatures, interliterary interaction, influence, West European context, national identity. 


\section{Introduction}

Historical and literary studies that appeared in Ukraine in the second half of the 19th century demonstrated the great importance of comparative literature in elucidation of sensitive issues of the national literary process development. It concerns above all understanding of Ukrainian literature, its relations with other Slavic and European literatures, creative writing of the East, which stimulated the evolution of comparative literary studies, which had its own peculiarities even at that time $[1,2]$.

Unfortunately, in the next stage, due to the situation during the Soviet period, the purpose and tasks of comparative studies changed dramatically and the development of the comparative literary theory "rolled up". Actualization, verging on absolutism, of interliterary relationship, primarily and mainly, the influence of Russian literature over the literatures of other nations, which came to the forefront, contributed to unification of the literatures that caused devaluation (depreciation) of comparative studies in the mainland Ukraine.

That is why scholars pay special attention to the analysis of national emigrant comparative literature of the 20th century (significant horizon of which is still awaiting for research), considering, first of all, its very important mission (role), i.e. insurance of the continuous evolution of Ukrainian comparative literary studies, given the impossibility of its full-fledged development under the pressure of ideology.

Contemporary scholars emphasize the fact that writings of expatriate scientists, who made use of the latest West European theoretical and methodological, as well as historical and literary approaches to the study of both artistic phenomena and literary processes in general - "scientific studies and researches of Dmytro Chizhevsky and Yuriy Sherekh (Shevelov), Yuriy Boyko-Blokhin and Leonid Biletsky, Yuriy Lavrinenko and Yuriy Lutsky, Igor Kachurovsky and Ivan Koshelivets, Dmytro Koziy and Oleksandra Chernenko, Luka Lutsiv and Yuriy Stefanyk, George Grabowicz and Ivan Fizer, Marko Pavlyshyn and Leonid Rudnytsky, Mikuláš Nevrlý and Stefan Kozak and many others are perceived now as definitive achievements, which thanks to their search milestones and interpretation discoveries ... were ahead of numerous works of Ukrainian literary critics committed then to the communist ideology" [3].

The foregoing applies entirely to the scientific heritage of Y. Boyko-Blokhin, who noted: "from the very beginning of my emigration, I have set me the goal not only to unmask the forced falsification of the Ukrainian culture in the homeland, but also to fill the gaps that other researchers could not fill from (in!) Ukraine" [4]. Researchers have repeatedly pointed out multi-vector and multidimensional activities of the philologist $[5,6]$. This is evidenced also with the works, focused mainly on systematization and popularization of the scientific and epistolary heritage of Y. Boyko-Blokhin [7, 8]. It is worth mentioning here papers devoted to comprehension of his literary and critical works [9], given the special role of criticism in the development of the national literary process in the exile [10].

The great importance of the scholar's research of comparative literature was pointed out by L. Grytsyk in her presentation "Problems of comparative study of literature in research work of Y. Boyko-Blokhin" at the scientific conference dedicated to commemoration in Ukraine of the 85 th birthday of the researcher in exile (Kyiv, May 21, 1994). However, the scientific activity of the scholar as a comparativist (despite the fact that his thoughts and ideas have not lost their relevance for modern comparative literary studies) remains basically out of sight of Ukrainian scientists. Y. Boyko-Blokhin's attitude to the problem of comparative study of Slavic literatures, which is extremely important for comprehension of the integrity of the literary concept of the scholar and very demonstrative for clarification of both peculiarities of the development of Ukrainian emigration comparativism in the second half of the 20th century and Slavic studies in the world in general, was not an object of a special study yet. This determines the rationale of the proposed article.

\section{Aim of research}

The aim of the study is to analyze views of Y. Boyko-Blokhin on the problem of comparative study of Slavic literatures with an emphasis on national peculiarities of each of them. 


\section{Y. Boyko-Blokhin's concept of research of comparative history of Slavic literatures}

Y. Boyko-Blokhin is a "prominent specialist in Slavic studies who ... began to use the modern methodology and thus got the sight of Ukrainian literature against the background of the world literature - with its level and its standards" [11], - that is how the emigration scholar is introduced by S. Bilokin, the author of the foreword to the book "Selected Works" of the literary critic, publication of which became possible in Ukraine only after it gained independence. It should be added that Y. Boyko at the same time actively continued the national tradition of study of Slavic literatures, especially Ukrainian literature, in the comparative aspect, using the approach initiated back in the 19th century by M. Drahomanov and I. Franko, and developed later on by M. Hrushevsky, M. Vozniak, F. Kolessa, L. Biletsky, V. Peretz and participants of his seminar, from M. Zerov and P. Filipovich to M. Chizhevsky and others, which was interrupted in the Ukraine in the 1930s under the pressure of Soviet ideology.

Y. Boyko-Blokhin distinguished three areas of research in the field of comparative literature: "1) study of an influence of a classical author on the world literature; 2) analysis of transformations of folklore and general literature patterns, poetic meters, tropes, etc., and, finally, styles; 3) comparative study of the history of national literatures" [12]. The scholar pointed out specific methods of study of each group, although he emphasized the "points of interdependence and interbreeding" between them. Precisely his comparative approach, consistent with understanding of "the history of literature as a science built on a broad comparative method (embracing universal writing)" [13], that was emphasized at some point by P. Filipovich, contributed to formation of a "panoramic view" of national literature and its study in a global context.

It is evident that ideas of Y. Boyko-Blokhin are in consonance with the concepts of modern scholars (in particular, D. Durišin, U. Weisstein and others) who, as D. Nalivayko observes, "traditionally connect comparative studies ... to the history of literature in the broadest sense" [14]. In particular, in his work "Revisiting the problem of comparative study of the history of East Slavic literatures (period of the 19th century)" [12] Y. Boyko-Blokhin, ahead of his time, highlighted issues that are of vital importance even today.

Being deeply aware of the trends in the development of world comparative literature, Y. Boyko forwarded the idea of reviewing "an approach to the tasks of Slavic studies in the realm of literature" [12]. In contrast to "modernization of the idea of Slavophilism," Y. Boyko-Blokhin defended understanding of the Slavic world as "a system of nations, internally defined world perceptions and worldviews that are in a state of interaction" [12], which respectively extends to their culture, including literature. However, the scholar advocated the conceptual position of comparative study, in particular, the modern one, stating that "under the term "interaction" we mean not only influences and mutual influences, but also mutual repulsions" [12]. It was pointed out yet by I. Franko, M. Hrushevsky, P. Filipovich, and, later on, by D. Chizhevsky.

While being of the same opinion as his predecessors, Y. Boyko emphasized: "in the study of influences and interactions, we should opt out of the simplified view popular in Soviet science that the influence is essential because it serves as a mediator for convergence of nations" [12]. The scholar did not exclude convergence in the process of influences, but he outlined that such convergence does not occur in all the cases.

According to him, the influences that lead to the passive perception of extraneous values may indicate either "spiritual fatigue of a nation or its subordination to an influencing nation. The latter is a manifestation of hidden (or even explicit) violence" [12]. To such influences the researcher contraposes creative influences, emphasizing his consent with the view of M. Hrushevsky, who considered: "borrowing is not an evidence of passivity, but of exalted activity" [12], and, by the way, it is entirely consonant with a position of O. Veselovsky related to "countercurrents".

Amplifying the ideas of M. Hrushevsky, Y. Boyko arrives to a conceptual conclusion that "in many cases influences lead to deepening of national peculiarities" [12]. I.Franko was guided by the similar logic of thought at some point [15]. This approach is characteristic for some concepts even now, e.g. Reizov's concept [16]. Y. Boyko-Blokhin assumed that "the stage of studying mostly literary generalities in comparativistics is coming to an end." He appealed on this occasion to the authors of "Theory of Literature" (1963), Wellek and Warren, who believed that "there is only one 
literature, just as there is only one art and only one mankind" [12]), prioritizing study of national peculiarities of each nation's literature. In this position the researcher is consonant with the views of contemporary comparativists [17, 18].

The views of Y. Boyko-Blokhin on the oeuvre of T. Shevchenko [19], as well as Franko [20], Lesia Ukrainka [21], Bahdanovich [22] in the West European literary context, with an emphasis on their originality, persuasively confirm the conviction of the scholar who declared ahead of his time: "peculiarities, as a runner to generalities, should consistently be the object of our studies" [12]. The scientist emphasized: "this is the only way for us to grab the pulse of the truly vital development of the Slavic literatures. It is inherent for the human spirit to observe itself in universal pursuits, in search of common sources and also in revealing the processes of unceasing creation of originality. And studying such national originality of literatures may be particularly fruitful in the broader perspective of comparativistics" (italics - O. T.) [12]. It is noteworthy that this conceptual thought of the scholar is very relevant today $[14,17,18]$. Such an opinion is shared by the maitre of contemporary national comparativistics, D.Nalivayko: "Elements of the literature movement unity exist in their diversity as in immanent reality, and so as not to fall into simplicity and schematism, it is a necessary to take this immanence as a basis and to go using inductive analysis of structures to discovery of common tendencies and typological matches of the general, regional or world development of literature as a component of spiritual culture" [14].

Y. Boyko-Blokhin is in consonance with ideas of contemporary scholars that "national literatures, as a rule, do not exist in one, but in several contexts, a role and significance of which is different, often with signs of a certain hierarchy" [14]. Therefore, Y. Boyko-Blokhin believed that "erection of the majestic edifice of the history of Slavic literatures should be done inductively, study of literatures of the Slavic world should be divided into separate Slavic groups, and perhaps even into epochs" [12]. Recognizing that "breakdown of the literatures should tend to three language branches, established in Slavic studies: eastern, western and southern" [12], the scholar drew attention to the possibility of deviations from this classification. In particular, as to Polish literature (that should be studied within West Slavic literatures) the researcher noted: "without considering the essential relationship of Poland with Ukraine, Belarus and Russia, such a comparative history of East Slavic branch is impossible and understanding of many Polish literary phenomena will be very incomplete" [12]. It is confirmed, for example, with careful attention given by Y. Boyko-Blokhin to the issue of reception by Ukrainian literature, especially by T. Shevchenko, of A. Mickiewicz's works. The scholar expresses a conceptual idea: it is possible to carry out the comparative description of Slavic romanticism only provided identification of the uniqueness of Byron's influences in various Slavic literatures. According to the scholar, just ignorance of "the character of Byronism in various Slavic countries" prevented V. Zhirmunsky "from spotlighting some important properties of Russian Byronism" [12]. The author substantiated his opinion in the German-language work "Influence of Byron in Russian, Ukrainian and Polish literature" [23], emphasizing particularities of Ukrainian Byronism.

Y. Boyko argued that East Slavic literatures of the 19th and 20th centuries should be classified as a separate object of study, noting that "expediency of such an approach is not only technical, the need arises from obvious distortions that have been seen for a long time in our literary criticism" - "thinking about Eastern Slavic literature in contemporary comparative literature is reduced mainly to coverage of Russian literature " [12]. Y. Boyko-Blokhin emphasized: "it is impossible not to be astonished at the sad phenomenon that this wide coverage of the Russian literary process of the $19^{\text {th }}-20^{\text {th }}$ centuries shifts and shades Ukrainian and Belarusian literatures that have great values, and not only for Slavic world "[12]. Sharing the opinion of D. Chizhevsky about the importance of investigation of the influence of Slavic literatures on West European ones, Y. Boyko-Blokhin considered: "If the work of Shevchenko at the proper time became accessible to writers of the Western world, its influence one way or another, just due to these realistic aspects of peasant life, would have reflected on the development of the European literary process" [19]. At the same time the scholar drew attention to the fact that "novel dedicated to the revolutionary struggle of workers appeared on the Ukrainian soil earlier than in any other European literature" 
[12]. In addition, the researcher noted that "Boryslav laughs" was written by Ivan Franko earlier than "Germinal" by E. Zola.

However, the scholar supposes that ignorance by Slavists of artistic and aesthetic achievements of Ukrainian and Belarusian literatures is associated not only with their lack of knowledge of languages of these literatures but also with the "inertia of ideological nature ... remnants of the worldview... that determines the role of Russian provinces for Ukraine and Belarus" [12]. Nevertheless, "both of these literatures that are abandoned in comparative studies deserve much more than the role of spotlights to illuminate certain aspects of Russian literature" [12], Y. Boyko says. It is noteworthy that, unfortunately, the situation has not changed even now, and the thoughts of the scholar remain very relevant. In particular, O. Pakhliovska states: "world Slavic studies today are basically Russian studies" [24].

Highly appreciating D. Chizhevsky's work "Comparative History of Slavic Literatures" [25], Y. Boyko, at the same time, pointed out that, regretfully, the peculiar heritage of I. NechuyLevytsky remained out of view of the author, and such talents as M. Baganovich and M. Kotsiubynsky were mentioned just superficially. The scholar draws attention to the writers of the "second, third order" as well.

"The gorgeous orchestra of European literatures does not play at its full pace," Y. Boyko said, "while Ukrainian and Belarusian instruments have not been added to it." In fact, Y. Boyko believed that his paramount task was to make these "instruments", first of all, Ukrainian writing, heard at the intercultural "forum" (V. Derzhavin).

In this light it is obvious that the scholar paid significant attention to understanding, first and utmost, of Ukrainian literature (works by T. Shevchenko, I. Franko, Lesia Ukrainka) in the West European context, focusing on its national artistic achievements as "results" (consequences) of "the competition at the world forum" (V. Derzhavin). It is convincingly proved as well by numerous German-language works of the scholar devoted to the works of national talented writers. In this regard, the following words of the author are very remarkable: "I often took Ukrainian literature at the international dimension, found place and specific weight of our literature in the world, and even more in the Slavic space" [4]. All of it was done, according to O. Pakhliovska, in order to "change the dramatic constant of Ukrainian culture: to melt the energy of different worlds, remaining for these worlds a space of myths" [24].

The scientist focused his attention on it, "thinking about how to build the history of Slavic literatures" [12]. Y. Boyko-Blokhin, reinterpreting the experience of Russian formalists and "deepening their analysis methods", believed that it is necessary to "move" just from the study of particularities of literary works, their language, composition details, depiction of the peculiarity of characters to comprehension of the style as a unifying principle. Here the researcher, in whose opinion, "we perceive the process of literary development in alternation of styles," has a resonance with D. Chizhevsky. The position of the scientist is amazing due to its relevance for modern comparativistics at the next, final, research level as well. "We want to see this literary progress against the background of the development of other arts," - the scholar expressed the opinion that was close, in particular, to the view of U. Weisstein [26] (incidentally, it was shared by D. Chizhevsky too, and now it is actualized, in particular, by D. Nalivayko), - our desire is to stay tuned to aesthetic concepts that connect literature with different kinds of art, with the movement of public opinion. And all of it should not be in conglomerate, but in comparison of national lines of divergence" [12]. It is very remarkable, especially from today's perspective, the comment of the researcher that "such a history of literature has not been written yet, but it is a dream of literary critics, if not all, then at least significant part of them" [12]. We would only add on our behalf: it still remains a dream only...

In this context, it is difficult to overestimate the importance of the views of Y. Boyko-Blokhin on the problem of comparative study of Slavic literatures (with an emphasis on elucidation of the distinctiveness, first of all, of his native literature!), which, ahead of time and keeping relevance even nowadays - that is convincingly proved by their consonance with the concepts of modern comparativists $[27,28]$ - ensure continuity of the development of national comparative literary studies, and also outline the prospects not only for its further progress, but also for the world Slavic studies in general. 
It is noteworthy how Y. Boyko-Blokhin deeply realized even several decades ago the points that contemporary scholars emphasize now: "Proper presence in the European Slavic studies of fully-fledged Ukrainian studies would greatly change the nature of this Slavic studies, would induced a need for review of a number of habitual schemes, and at the same time would change the dynamics and trends of the search for Ukrainian studies as such... This is obvious even now, when Ukrainian studies are still slowly starting to gain positions in the international context "[24].

\section{Results of the study}

1. The views of Y. Boyko-Blokhin on the problem of comparative study of Slavic literatures in the context of modern comparativistics are analyzed for the first time ever.

2. The efficiency and potential of the scholar's concept of comparative study of East Slavic literatures, aimed at elucidating of specific features of each of them and understanding of their place in Common Slavic and West European literary space are substantiated.

Consideration of the scholar's thoughts will surely deepen future comparative history of Slavic literatures, studies devoted to Ukrainian literature in Slavic and world contexts, as well as academic courses related to the history of Ukrainian and Slavic literatures.

3. The great importance of the thoughts of Y. Boyko-Blokhin - who developed traditions of national comparative studies, and, at the same time, used the latest West European methodology for support of the continuous progress of Ukrainian comparative literature, given the impossibility of its full-fledged advance during the Soviet period, is accentuated.

\section{Conclusions}

1. Y. Boyko-Blokhin's concept of comparative study of Slavic literatures, with an emphasis on understanding their interrelations that reveal national particularities of each of them, outlines new horizons for further scientific research.

2. The scholar's conclusion as for the expediency of separation of East Slavic "branch" in the paradigm of the world Slavic studies opens new opportunities for deeper and more comprehensive study, in particular of Ukrainian literature, in Common Slavic and West European literary contexts, thus contributing to the progress of Slavic studies in general.

3. Te scientific work of Y. Boyko-Blokhin as a comparativist (in the first place, his conception of comparative study of Slavic literatures, which is still valid nowadays) is a significant achievement of national comparative literary studies at the world-class level.

\section{References}

[1] Hrytsyk, L. (2010). Ukrainian comparative studies: conceptual projections. Donetsk: YugoVostok, 297.

[2] Aleksandrova, H. (2009). Transition. (Ukrainian comparative literary studies of the end of the 19th century - first third of 20th century). Kyiv: Publishing and Printing Center of Kyiv University, 415.

[3] Khorob, S. (2005). Scientific universe of Vladimir Derzhavin. Derzhavin V. Literature and literary studies (Selected theoretical and critical works). Ivano-Frankivsk: Play, 492.

[4] Boyko, Y. (1992). On the eve of the eightieth jubilee. Yuriy Boyko. Selected works. Kyiv: Medekol, 6-10.

[5] Scholz, F. (1930-1988). Laudatio für Jurij Bojko-Blochyn. Jurij Bojko-Blochyn. Schriftenverzeichnis 1930-1988. Heidelberg: Carl Winter, Universitätsverlag, 7-15.

[6] Melnyk, V. (1992). Revival of the future. Word and time, 7, 16-17.

[7] Teterina, D. (1998). Life and work of Yuriy Boyko-Blokhin. Munich-Kyiv: Olena Teliha Publishing House.

[8] Blokhin, D. (2017). Epistolary heritage of Yuriy Boyko-Blokhin. Vol. 3. Munich-Ternopil, 609.

[9] Kopaniuk, M. Y. (2012). Boyko-Blokhin (1909-2002) - literary critic. Scientific notes of Ukrainian history. Pereyaslav-Khmelnytskiy, 92-99.

[10] Ilnytskiy, M. (2014). "Small literary revival": literary criticism of the period of Ukrainian Art Movement. Signs of the epoch and facets of talent. Kyiv: "KLIO” Publishing House LLC, 109-128.

[11] Bilokin, S. (1992). In lieu of a preface. Yuriy Boyko. Selected works. Kyiv: Medekol, 3-6. 
[12] Boyko, Y. (1981). Revisiting the problem of comparative study of the history of East Slavic literatures. Vol. 3. Yuriy Boyko. Selecta. Munich, 229-240.

[13] Fylypovych, P. (1971). Shevchenko and Romanticism. Literature. New York - Melbourne: Printing house of B. Ignatov in Melbourne, 53-75.

[14] Nalyvayko, D. (2007). Comparative studies in the system of literary disciplines. Comparative studies and history of literature. Kyiv: AKTA, 3-42.

[15] Franko, I. (1981). Internationalism and nationalism in contemporary literatures. Collected works. Vol. 31. Kyiv: Naukova dumka, 33-44.

[16] Reizov, B. (1986). History and theory of literature. Leningrad, 319.

[17] Durisin, D. (1979). Theory of comparative literary studies. Moscow: Progress, 320.

[18] Dima, A. (1977). Principles of comparative literary studies. Moscow: Progress, 229.

[19] Boyko, Y. (1992). Creative heritage of Taras Shevchenko against the background of West European literature. Yuriy Boyko. Selected works. Kyiv: Medekol, 11-73.

[20] Boyko, Y. (1992). Revisiting the problem of evolution of Franko's style. Yuriy Boyko. Selected works. Kyiv: Medekol, 94-109.

[21] Boyko-Blochyn, Y. Die Stilrecherchen Lesja Ukrainkas auf dem Hintergrund der Weltliteratur. Lesja Ukrainka und die europäische Literatur. Böhlau - Verlag - Köln - Weimar - Wien, 11-32.

[22] Boyko-Blochyn, Y. Maksim Bahdanovic. Gegen den Storm. Ausgewählte Beiträge zur Geschichte der slavischen Literaturen. Heidelberg: Carl Winter. Universitatsverlag, 122-135.

[23] Boyko-Blochyn, Y. Byrons Einfluss auf die russische, ukrainische und polinische Literatur. Gegen den Storm. Ausgewählte Beiträge zur Geschichte der slavischen Literaturen. Heidelberg: Carl Winter. Universitatsverlag, 28-54.

[24] Pakhliovska, O. (2008). Ukrainian literature from the point of view of the West: aberration aspects and causes. Ave, Europa!, 101-112.

[25] Chizhevsky, D. (2005). Comparative history of Slavic literatures. Kyiv: "Academia" Publishing Center, 288 .

[26] Weisstein, U. (2009). Comparing literature and art: Current trends and prospects in critical theory and methodology. Contemporary comparative literature: strategies and methods. Anthology. Kyiv: Publishing House "Kyiv-Mohyla Academy”, 372-392.

[27] Paskhar'yan, N. T. (2016). Universitetskiy kurs istorii literatury i sovremennost': k probleme vzaimodeystviya obshhey i sravnitel'noy istorii literatur. Visnik Dnipropetrovs'kogo universitetu imeni Al'freda Nobelya. Seriya "Filologichni nauki”, 2 (12), 25-31.

[28] Toudoire-Surlapierre, F. (2013). Notre besoin de comparaison. Orisons, 187. 